OPEN ACCESS

Edited by:

Gloria Ravegnini,

University of Bologna, Italy

Reviewed by:

Elisa Giovannetti,

VU University Medical Center, Netherlands

Sonja Klebe

Flinders University, Australia

*Correspondence:

Vincenzo Ciminale

v.ciminale@unipd.it

${ }^{\dagger}$ These authors have contributed equally to this work

Specialty section:

This article was submitted to Pharmacology of Anti-Cancer Drugs,

a section of the journal

Frontiers in Oncology

Received: 03 June 2019

Accepted: 23 July 2019

Published: 14 August 2019

Citation:

Cavallari I, Urso L, Sharova E, Pasello G and Ciminale V (2019)

Liquid Biopsy in Malignant Pleural Mesothelioma: State of the Art

Pitfalls, and Perspectives.

Front. Oncol. 9:740.

doi: 10.3389/fonc.2019.00740

\section{Liquid Biopsy in Malignant Pleural Mesothelioma: State of the Art, Pitfalls, and Perspectives}

\author{
Ilaria Cavallari ${ }^{1 \dagger}$, Loredana Urso ${ }^{2 \dagger}$, Evgeniya Sharova ${ }^{1 \dagger}$, Giulia Pasello ${ }^{1}$ and \\ Vincenzo Ciminale ${ }^{1,2 *}$ \\ ${ }^{1}$ Immunologia e Diagnostica Molecolare Oncologica (IDMO), Istituto Oncologico Veneto IOV- IRCCS, Padova, Italy, \\ ${ }^{2}$ Department of Surgery, Oncology and Gastroenterology, Università degli Studi di Padova, Padova, Italy
}

Malignant pleural mesothelioma (MPM) is an aggressive tumor linked to asbestos exposure. Although the risk factors for MPM are well-known, the majority of MPM patients are diagnosed at an advanced stage and have a very poor prognosis. Circulating biomarkers for early diagnosis remain to be identified, and the current standard for MPM diagnosis relies on pleural biopsies. Robust non-invasive tests for the screening of asbestos-exposed subjects are therefore an important unmet clinical need. This review provides a critical summary of recent liquid biopsy-based studies aimed at discovering novel blood-based circulating biomarkers for the early diagnosis and prognostic stratification of MPM patients.

Keywords: microRNA, prognostic stratification, early diagnosis, asbestos exposure, liquid biopsy, mesothelioma

\section{INTRODUCTION}

Malignant pleural mesothelioma (MPM) is a rare cancer with increasing incidence and dismal prognosis due to its aggressiveness and lack of effective treatments (1-3).

Asbestos exposure is considered the main causative factor for MPM, with a decades-long latency between start of exposure and clinical diagnosis (4). Prolonged exposure to inhaled asbestos fibers trigger an increase in reactive oxygen species (ROS) and inflammatory cytokines in the pleural microenvironment, both of which are key drivers of MPM carcinogenesis $(5,6)$. However, despite the high ROS burden, MPM is characterized by a low mutation load (7), with tumor suppressors (CDKN2A, BAP1, NF2, LATS2) the most frequently mutated genes involved in MPM pathogenesis (8).

The current standard for the diagnosis and genetic profiling of most tumors involves the use of tissue biopsies (9). However, given its invasive nature, tissue biopsy is burdened with considerable patient morbidity and costs for the health care systems $(9,10)$. The histopathological diagnosis of pleural biopsies is difficult and may require FISH (fluorescent in situ hybridization) of the CDKN2A locus and immunohistochemistry for p16 and BAP1 (11) when invasion is not clearly demonstrated based on the histology, and to confirm the diagnosis of mesothelioma in pleural effusions.

The onset of MPM is insidious and most patients have advanced disease at presentation. Current imaging methods are inadequate for screening and for differential diagnosis of pleural plaques vs. malignant mesothelioma (12). The availability of a robust non-invasive test for the screening of asbestos-exposed subjects is therefore an important unmet clinical need.

"Liquid biopsy" of biological fluids (e.g., plasma and serum, urine, saliva, cerebrospinal fluid, pleural fluid, ascites, stool) is emerging as a powerful tool for non-invasive diagnosis, screening, prognosis, and stratification of cancer patients. This approach is based on the fact that tumor cells 
release molecules (proteins, DNA, RNA), circulating tumor cells (CTC), and extra cellular vesicles (EV) that can be used as biomarkers (13) (Figure 1). Liquid biopsies may be repeated frequently to provide a more detailed picture of the natural history of the disease with a longitudinal assessment of tumor burden and clues about clonal evolution and emergence of drugresistant clones leading to clinical relapse $(9,14)$.

The following sections provide a critical overview of recent studies describing novel circulating biomarkers for the early diagnosis and prognostic stratification of MPM patients.

\section{CIRCULATING TUMOR PROTEINS}

\section{Mesothelin}

Mesothelin (MSLN) is a cell-surface glycoprotein expressed by mesothelial cells. It is synthesized as a $70-\mathrm{kDa}$ precursor which is cleaved by Furin protease to produce the mature form of Mesothelin and Megakariocyte Potentiating Factor (MPF) (15). Mesothelin is overexpressed in ovarian cancer, pancreatic cancer (15) and MPM, especially in the epithelioid and biphasic subtypes (16).

A soluble form of Mesothelin, named Soluble Mesothelinrelated peptide (SMRP), is shed by the tumor cells into the circulation (17-19). Although SMRP is not specific for MPM $(17,20,21)$, its role as early biomarker for the screening of asbestos-exposed subjects has been extensively studied (Figure 1, Table 1).

Almost all of these studies used the U. S. Food and Drug Administration (FDA)-approved Mesomark ELISA assay to detect all soluble forms of the protein. Mesomark is a reliable assay that is not affected by the presence of other molecules (e.g., hemoglobin, triglycerides, bilirubin) (20).

The first study investigating SMRP in the context of MPM showed increased SMRP levels in serum samples from 37 out of $44 \mathrm{MPM}$ patients compared to 40 healthy asbestos-exposed subjects (22). The test also distinguished MPM patients from 18 patients affected by non-neoplastic asbestos-related disease and 122 patients with inflammatory lung diseases or other cancers. Unfortunately, SMRP levels showed low accuracy in identifying patients with sarcomatoid MPM and low tumor size $(<1 \mathrm{~cm})$. In this study, the authors did not take into account confounding factors such as age, renal dysfunction, and body mass index (BMI) that may "per se" increase SMRP levels (37-40). Other studies confirmed these results $(23,24,26-28,41,42)$, but were characterized by high heterogeneity regarding the selection of the control study population and cut-off values (18). A meta-analysis of data from 16 different studies indicated low accuracy for early diagnosis because of low sensitivity. Indeed, low SMRP levels did not exclude the presence of malignancy, especially in early-stage disease (18).

Although SMRP cannot be considered an early diagnostic biomarker for surveillance programs, it seemed to be effective in predicting response to chemotherapy and patient survival. This is an important issue, as quantitative radiological measures are difficult for this cancer. In three prospective studies enrolling, respectively, 96, 107, and 100 MPM patients, high baseline SMRP levels significantly correlated with shorter survival $(24,25,43)$. In
2010, Creaney et al. performed a prospective evaluation of serum SMRP levels over time in patients undergoing chemotherapy $(N=55)$. These authors found a strong correlation between radiological responses (measured by CT scans according to modified RECIST criteria) and SMRP variations. Specifically, an increase $>25 \%$ was associated with progressive disease (PD), a decrease $>25 \%$ with partial response (PR), and no changes with stable disease (SD). Log-rank analysis showed that a decrease in SMRP was strongly associated with longer survival (44). The results were confirmed in another study, although the authors measured SMRP in the plasma and set the cut-off at $10 \%$ variation (45). These studies have some limitations such as the small sample size and the heterogeneity of the treatments received; nevertheless, the usefulness of SMRP as an indicator of tumor response deserves further investigation.

Anti-Mesothelin antibodies (e.g., immunotoxin SS1P) are being tested for MPM and other cancers. In these patients MPF (Megakariocyte Potentiating Factor) may be used as a biomarker to evaluate response to therapy as it does not bind the therapeutic antibodies (46). Serum MPF was analyzed in patients enrolled in two clinical trials evaluating SS1P efficacy: a phase I trial tested first line treatment with SS1P in combination with Cisplatin/Pemetrexed (47) and a pilot study investigated SS1P in association with cyclophosphamide and pentostatin in previously treated patients (48); results showed that all patients who experienced PR showed a strong decrease in MPF expression, suggesting that serum MPF might predict clinical outcome (49). However, these studies were carried out on a low number of patients.

\section{Osteopontin}

Osteopontin is an integrin-binding protein, implicated in cell-matrix interactions. It is overexpressed in several types of cancers (50), including MPM (29). Pass et al. analyzed serum samples from 69 asbestos-exposed subjects, 45 smoking subjects and 75 MPM patients. The duration of asbestos exposure independently correlated with Osteopontin serum levels (Figure 1). Furthermore, serum Osteopontin was higher in MPM patients than in asbestos-exposed controls (133 \pm 10 vs. $30 \pm 3 \mathrm{ng} / \mathrm{ml}$ ). Receiver Operating Characteristic (ROC) analysis demonstrated that the most accurate cut-off value for stage I disease was $62.4 \mathrm{ng} / \mathrm{ml}$, with $84.6 \%$ sensitivity and $88.4 \%$ specificity. Unfortunately, in another study serum Osteopontin failed to distinguish MPM patients from patients with pleural metastasis of different carcinomas or from subjects with nontumoral asbestos-related diseases (25). Another study suggested that plasma Osteopontin is a more stable and reliable marker than serum Osteopontin; nevertheless, conclusive data about its diagnostic accuracy are still lacking $(30,31,51)$. Combined assessment of SMRP and Osteopontin, was not more informative than SMRP alone $(30,31,45,52)$ (Table 1).

\section{Fibulin-3}

Research for circulating biomarkers of MPM also included Fibulin-3 as a single biomarker or in combination with Mesothelin. Fibulin-3 is a secreted glycoprotein implicated in cell proliferation and migration (34). In the first report, plasma 


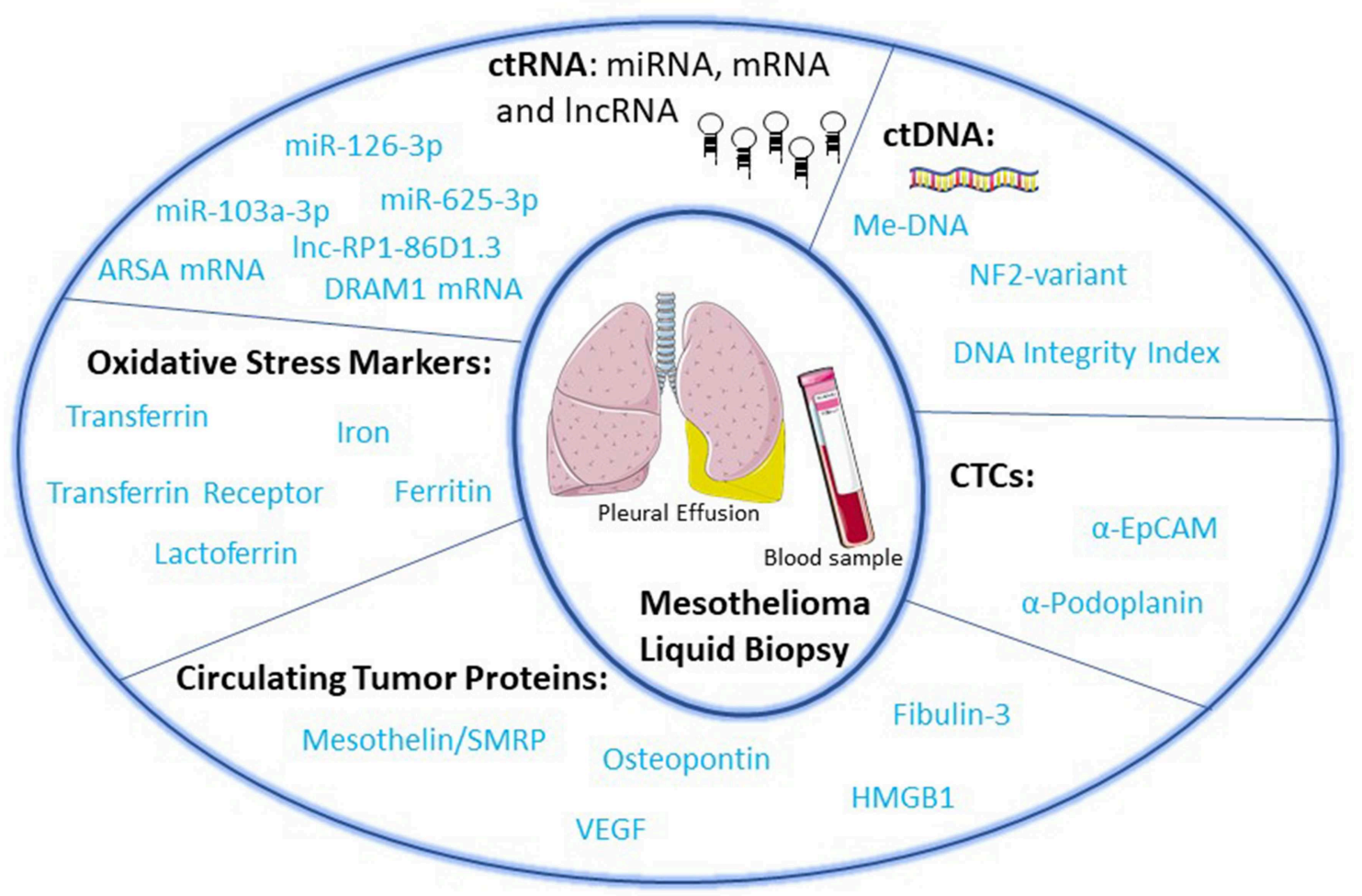

FIGURE 1 | Circulating biomarkers in malignant pleural mesothelioma.

levels of Fibulin-3 were measured in a total of 92 MPM patients, 136 healthy asbestos-exposed controls and 93 patients affected by other cancers. The subjects enrolled in the study belonged to two different cohorts. Fibulin-3 was found to be higher in MPM patients compared to control groups; this alteration was not related to duration of asbestos exposure, age, sex, histologic subtype or tumor stage (32). ROC analysis showed an AUC of 0.99 and the best cut-off value was $52.8 \mathrm{ng} / \mathrm{ml}$ for all MPM patients and $46 \mathrm{ng} / \mathrm{ml}$ for stage I/II disease. Based on these results the authors concluded that Fibulin- 3 was the best biomarker analyzed so far. However, in an analysis of a validation cohort comprising 48 MPM patients and 96 asbestos-exposed controls, the accuracy of Fibulin-3 did not differ from that reported for Mesothelin (AUC 0.87) (32). This discrepancy between training and validation sets may be due to differences in the cohorts analyzed $(36,53)$. Other studies indicated that Fibulin-3 was not useful for discriminating MPM patients from patients affected by other diseases (33), and did not perform as well as Mesothelin (54) (Table 1).

\section{Inflammatory and Angiogenic Factors}

Chronic inflammation is considered a key determinant of MPM carcinogenesis (55). Inhaled asbestos fibers accumulate in the pleura and activate an inflammatory response. As macrophages cannot eliminate these fibers, inflammatory cytokines and growth factors are continuously produced, promoting malignant transformation. Tumor-associated macrophages (TAM) also produce, and induce production of cytokines and growth factors that enhance tumor growth and invasiveness (56).

The tight link between inflammation and cancer aggressiveness is supported by several studies demonstrating that the neutrophil-to-lymphocyte ratio (NLR), an indicator of systemic inflammation, is an independent predictor of poor prognosis in several cancers, including MPM (57-59). Based on this knowledge, the evaluation of inflammation markers was proposed for the diagnostic/prognostic stratification of MPM patients.

High Mobility Group B 1 (HMGB1) belongs to the family of damage-associated molecular pattern proteins (DAMPs) and is considered a key mediator of asbestos-induced inflammation $(60,61)$. In physiological conditions, HMGB1 is localized in the nucleus, where it functions as a chromatin-binding protein and is released by cells undergoing necrosis. In pathological conditions, myeloid cells and cancer cells can actively secrete a hyper-acetylated form of HMGB1. In the extracellular space, HMGB1 activates innate and adaptive immunity and acts as a pro-oncogenic factor binding to Toll like Receptors (TLRs) and RAGE (receptor of advanced glycation end products) (62). Jube et al. demonstrated that HMGB1 and its receptors are highly expressed in MPM tissues and cell lines. Exposure of normal mesothelial cells to asbestos induces necrosis, resulting in release of HMGB1 (Figure 1). Transformed MPM cells actively secrete acetylated HMGB1, which promotes cell proliferation and invasiveness in an autocrine manner (61). Consistent with this 
TABLE 1 | Circulating protein biomarkers evaluated for early diagnosis in MPM.

\begin{tabular}{|c|c|c|c|c|c|}
\hline $\begin{array}{l}\text { Protein } \\
\text { biomarker }\end{array}$ & Study design & Method & Sample & Study results & References \\
\hline \multirow[t]{5}{*}{ SMRP } & $\begin{array}{l}\mathrm{AEXP}=40 \\
\mathrm{MPM}=44 \\
\mathrm{ARD}=38 \\
\mathrm{ILD}=92 \\
\mathrm{OC}=38\end{array}$ & ELISA & Serum & $\begin{array}{l}\text { MPM vs. AEXP } \\
\text { cut-off } 0.22 \mathrm{nmol} / \mathrm{L} \\
\text { Sensitivity: } 84 \% \text {, } \\
\text { Specificity: } 83 \% \\
\text { MPM vs. PD } \\
\text { cut-off } 0.22 \mathrm{nmol} / \mathrm{L} \\
\text { Sensitivity: } 84 \% \text {, } \\
\text { Specificity: } 100 \% \\
\text { MPM vs. OC } \\
\text { cut-off } 0.22 \mathrm{nmol} / \mathrm{L} \\
\text { Sensitivity: } 84 \%, \\
\text { Specificity: } 95 \%\end{array}$ & (22) \\
\hline & $\begin{array}{l}\text { MPM }=60 \\
\text { Mets }=30 \\
A R D=23\end{array}$ & ELISA & Serum & $\begin{array}{l}\text { MPM vs. ARD } \\
\text { AUC = } 0.87 \\
\text { cut-off } 0.93 \mathrm{nmol} / \mathrm{L} \\
\text { Sensitivity: } 80 \% \\
\text { Specificity: } 82.6 \% \\
\text { MPM vs. Mets } \\
\text { AUC }=0.693 \\
\text { cut-off } 1.85 \mathrm{nmo} / \mathrm{L} \\
\text { Sensitivity: } 58.3 \% \\
\text { Specificity: } 73.3 \%\end{array}$ & (23) \\
\hline & $\begin{array}{l}\mathrm{HC}=54 \\
\mathrm{AEXP}=203 \\
\mathrm{ARD}=130 \\
\mathrm{MPM}=107\end{array}$ & ELISA & Serum & $\begin{array}{l}\text { MPM vs. All } \\
\text { AUC }=0.77 \\
\text { cut-off } 1 \mathrm{nmol} / \mathrm{L} \\
\text { Sensitivity: } 68.2 \% \\
\text { Specificity: } 80.5 \%\end{array}$ & (24) \\
\hline & $\begin{array}{l}\text { AEXP }=112 \\
\text { Mets }=43 \\
\text { ARD }=33 \\
M P M=96\end{array}$ & ELISA & Serum & $\begin{array}{l}\text { MPM vs. AEXP } \\
A \cup C=0.866 \\
M P M \text { vs. ARD } \\
A \cup C=0.719\end{array}$ & (25) \\
\hline & $\begin{array}{l}\text { AEXP/ARD = } \\
66, \mathrm{MPM}=90\end{array}$ & ELISA & Serum & $\begin{array}{l}\text { MPM vs. AEXP/ARD } \\
\text { AUC }=0.81 \\
\text { cut-off } 1.9 \mathrm{nmol} / \mathrm{L} \\
\text { Sensitivity: } 60 \% \\
\text { Specificity: } 89.2 \%\end{array}$ & (26) \\
\hline \multirow[t]{3}{*}{ Osteopontin } & $\begin{array}{l}\text { AEXP/ARD }= \\
69, F S=45, \\
M P M=75\end{array}$ & ELISA & Serum & $\begin{array}{l}\text { MPM vs. AEXP/ARD } \\
\text { AUC }=0.888 \\
\text { cut-off } 48.3 \mathrm{ng} / \mathrm{ml} \\
\text { Sensitivity: } 77.6 \% \\
\text { Specificity: } 85.5 \% \\
\text { Stage I MPM vs. AEXP/ARD } \\
\text { AUC }=0.906 \\
\text { cut-off } 62.4 \mathrm{ng} / \mathrm{ml} \\
\text { Sensitivity: } 84.6 \% \\
\text { Specificity: } 88.4 \%\end{array}$ & (29) \\
\hline & $\begin{array}{l}\mathrm{AEXP}=112 \\
\text { Mets }=43 \\
\mathrm{ARD}=33 \\
\mathrm{MPM}=96\end{array}$ & ELISA & $\begin{array}{l}\text { Serum, } \\
\text { Plasma }\end{array}$ & $\begin{array}{l}\text { MPM vs. AEXP } \\
\text { AUC } 0.724 \\
\text { MPM vs. Mets } \\
A \cup C=0.689 \\
\text { MPM vs. ARD } \\
\text { AUC }=0.677\end{array}$ & (25) \\
\hline & $\begin{array}{l}\mathrm{AEXP}=93 \\
\mathrm{ARD}=111 \\
\mathrm{MPM}=31\end{array}$ & ELISA & Plasma & $\begin{array}{l}\text { MPM vs. AEXP/ARD } \\
A \cup C=0.785\end{array}$ & (30) \\
\hline
\end{tabular}


TABLE 1 | Continued

\begin{tabular}{|c|c|c|c|c|c|}
\hline $\begin{array}{l}\text { Protein } \\
\text { biomarker }\end{array}$ & Study design & Method & Sample & Study results & References \\
\hline & $\begin{array}{l}\mathrm{ARD}=89 \\
\mathrm{MPM}=66\end{array}$ & ELISA & Plasma & $\begin{array}{l}\text { MPM vs. ARD } \\
A \cup C=0.763\end{array}$ & (31) \\
\hline & $\begin{array}{l}\mathrm{HC}=120 \\
\mathrm{AEXP}=123 \\
\mathrm{ARD}=279 \\
\mathrm{MPM}=24\end{array}$ & ELISA & Serum & $\begin{array}{l}\text { MPM vs. All } \\
\text { AUC } 0.86 \\
\text { cut-off } 17.273 \mathrm{nmol} / \mathrm{L} \\
\text { Sensitivity: } 75 \% \\
\text { Specificity: } 86 \%\end{array}$ & (28) \\
\hline & $\begin{array}{l}\text { Validation } \\
\text { study: } \mathrm{AEXP}= \\
96, \mathrm{MPM}=48\end{array}$ & ELISA & Plasma & $\begin{array}{l}\text { MPM vs. AEXP } \\
A \cup C=0.87\end{array}$ & \\
\hline & $\begin{array}{l}\text { Non-MPM = } \\
56, \mathrm{MPM}=84\end{array}$ & ELISA & Plasma & $\begin{array}{l}\text { MPM vs. Non-MPM } \\
A \cup C=0.632\end{array}$ & (33) \\
\hline $\begin{array}{l}\text { Acetylated } \\
\text { HMGB1 }\end{array}$ & $\begin{array}{l}\mathrm{HC}=20, \\
\mathrm{AEXP}=20, \\
\mathrm{BE}=13, \mathrm{OC} \\
=25, \mathrm{MPM}= \\
22\end{array}$ & $\begin{array}{l}\text { Mass } \\
\text { Spectrometry }\end{array}$ & Serum & $\begin{array}{l}\text { MPM vs. AEXP } \\
\text { AUC = } 1 \\
\text { Cut-off } 2 \mathrm{ng} / \mathrm{ml} \\
\text { Sensitivity: } 100 \% \\
\text { Specificity: } 100 \% \\
\text { MPM vs. BE/OC } \\
\text { AUC }=0.837 \\
\text { Cut-off } 9.70 \mathrm{ng} / \mathrm{ml} \\
\text { Sensitivity: } 81.82 \% \\
\text { Specificity: } 89.47 \%\end{array}$ & (35) \\
\hline
\end{tabular}

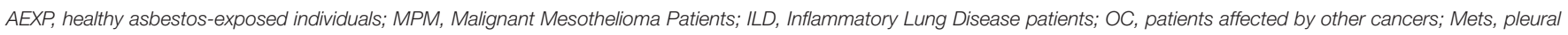
metastasis of carcinomas; HC, non-exposed healthy controls; ARD, benign asbestos-related disease patients; FS, former smoker individuals; BE, patients with benign effusion.

notion, Napolitano et al. showed that asbestos-exposed subjects $(N=42)$ had higher serum levels of total HMGB1 compared to non-exposed control $(N=20)$. In healthy exposed individuals $(N$ $=20$ ) the majority of serum HMGB1 was in the non-acetylated form (90\%), while in MPM patients $(N=22)$ the acetylated form was prevalent (67\%). ROC analysis showed that serum levels of acetylated HMGB1 discriminated healthy exposed controls from MPM patients with high accuracy (cut-off $=2 \mathrm{ng} / \mathrm{ml}$; $\mathrm{AUC}=1 ; 100 \%$ specificity, $100 \%$ sensitivity). Importantly, tumor stage did not influence acetylated HMGB1 levels (35) (Table 1). Although these results were obtained with a small number of subjects, they provide groundwork for future investigations on larger cohorts aimed at validating acetylated HMGB1 as an early diagnostic marker.

The angiogenic factor VEGF, a key stimulator of tumor neoangiogenesis, is overexpressed in MPM tissues (63-65). VEGF levels are also increased in pleural effusions (PE) of MPM patients compared to patients affected by non-malignant pleural diseases or lung cancer (66). Yasumitsu et al. showed that serum VEGF was higher in MPM patients $(N=51)$ compared to control patients with non-tumoral asbestos-related diseases $(N=29)$. Setting a cut-off at $460 \mathrm{pg} / \mathrm{ml}$, these authors showed a strong correlation between high serum VEGF and shorter patient survival (67). A predictive/prognostic role of VEGF in MPM has also been described. Baseline serum levels of VEGFA and VEGF receptor 2 (VEGFR-2) correlated with radiological response in patients treated with the multitarget tyrosine kinase inhibitor Sunitinib Malate (68). In patients with high baseline serum levels of VEGF, its decrease after 8 weeks of thalidomide treatment correlated with longer patient survival (69). Although these results are promising, they should be considered cautiously. Serum VEGF may not really reflect its circulating levels because it may be released by platelets during in vitro blood clotting (70). Considering that platelet count is an independent prognostic factor for MPM patient survival (71), VEGF should probably be evaluated in plasma instead of serum samples.

\section{Markers of Oxidative Stress}

Reactive oxygen species (ROS) and reactive nitrogen species (RNS) are key mediators of asbestos toxicity (72). ROS and RNS are generated by asbestos through two main mechanisms. First, the different forms of asbestos fibers contain iron, which increases the generation of hydroxyl radicals through the reactions of Fenton and Haber-Weiss $(73,74)$. Consistent with this notion, $\mathrm{X}$-ray imaging and spectroscopy studies showed that asbestos fibers in tissues contain iron in the form of ferritin and haematite (75). Second, inhaled asbestos fibers are internalized by alveolar epithelial cells (AEC) and alveolar macrophages (AM); the activation and attempted phagocytosis by AM and neutrophils lead to activation of vacuolar NADPH oxidase and myeloperoxidase, which generate ROS and hypochlorite radicals in the microenvironment. Undigested asbestos fibers are coated 
with a mucopolysaccharide, generating the pathognomonic asbestos bodies, and with iron protein complexes, resulting in the ferruginous bodies, which further enhance ROS production and local inflammation.

Bronchoalveolar lavage fluid (BALF) of asbestos-exposed patients $(N=14)$ exhibited an increase in several markers of inflammation and altered iron and ROS homeostasis (i.e., iron, transferrin, transferrin receptors, lactoferrin, and ferritin) compared to unexposed controls $(N=10)$ and asbestos-exposed subjects $(N=14)$ (76) (Figure 1). It will be interesting to test ROS-related markers in the peripheral blood of MPM patients and asbestos-exposed individuals.

\section{CIRCULATING microRNAs (miRNAs)}

miRNAs are small non-coding RNAs that regulate the expression of a vast number of mRNAs (77). Tumor cells exhibit distinctive miRNA signatures $(78,79)$ and can release miRNAs as a result of cell death and active secretion (80). Such cell-free circulating miRNAs (cfmiRNA) are relatively stable, since they are incorporated into membrane-bound vesicles or bound to ribonucleoprotein complexes (81).

Studies of cfmiRNAs are curbed by major problems in data normalization, given the difficulties in identifying "bona fide" housekeeping miRNA in biological fluids that can be used for normalization. Biases linked to the choice of an appropriate reference can be circumvented by using the miRNA ratio approach $(82,83)$, which is based on the calculation of ratios between upregulated and downregulated miRNAs in the same patient.

Several studies investigated the cfmiRNA profile in mesothelioma patients with the aim of identifying markers for early diagnosis and prognostic stratification (84). This section focuses mainly on miR-126-3p, miR-103a-3p, and miR-625, 3 miRNAs that appear to be consistently altered in MPM patients (Table 2).

Santarelli et al. showed that miR-126-3p is strongly downregulated in serum samples from MPM patients $(N=44)$ compared to samples from healthy volunteers $(N=50)$ or asbestos-exposed subjects $(N=196)$ (85). ROC curve analysis indicated that this miRNA distinguished MPM patients from asbestos-exposed individuals with $73 \%$ sensitivity and $74 \%$ specificity (85). The combined upregulation of soluble SMRP and downregulation of miR-126-3p was associated with a high risk of mesothelioma development. However, these data were normalized using the small nucleolar RNA RNU6 (U6), which is known to be present at low and variable levels in blood (83) and may be altered in chronic inflammation (95), which is very common in asbestos-exposed individuals.

Tomasetti et al. (86) confirmed that miR-126-3p discriminates MPM patients $(N=45)$ from healthy controls $(N=56)$ (sensitivity $80 \%$, specificity $60 \%$ ) and that its levels are lower in MPM patients with poor prognosis compared to those with better clinical outcome and to patients with non-small cell lung cancer
$(N=20)$. In this study, the samples were normalized to spiked-in cel-miR-39, endogenous U6 or both (86).

Interestingly, the diagnostic performance of miR-126-3p was significantly improved when combined with Mesothelin and methylation of the thrombomodulin promoter (AUC 0.857, 95\% CI 0.767-0.927) (87) (see also section on DNA methylation).

In apparent contrast with these studies, Mozzoni et al. (88) did not confirm the ability of miR-126-3p to discriminate MPM patients $(N=32)$ from asbestos-exposed controls $(N=14)$, and did not observe a correlation between the levels of miR126-3p in the plasma and in the MPM tissues $(N=24)$. However, miR-126-3p was able to distinguish MPM patients $(N=32)$ and asbestos-exposed patients $(N=14)$ from control subjects with non-cancerous pulmonary diseases $(N=$ 15). It must be noted that in this study, the authors used different normalizer RNAs for plasma (miR-146) and tissue (U6, RNU44, RNU48). More recently, Weber et al. (89) analyzed the levels of miR-126-3p, miR-132-3p, and miR-103a-3p in plasma samples obtained a median of 8.9 months prior to the diagnosis of MPM $(N=17)$, and compared them to asbestosexposed controls $(N=34)$. This study indicated $0 \%$ sensitivity of these miRNAs considering a specificity of $98 \%$. Based on these findings, the authors concluded that these miRNAs are unsuitable as biomarkers for early detection of MPM in asbestosexposed individuals. However, it must be noted that, to permit a comparison with previous studies, the authors normalized miR-126-3p against U6, miR-132-3p against miR-146b-5p, and miR-103a-3p against miR-125a (89). As the authors suggest, it would be desirable to employ a common normalizer for all these miRNAs.

Kirschner et al. demonstrated higher levels of miR-625-3p in the serum of MPM patients $(N=30)$ compared to asbestosexposed subjects $(N=10$ ) (accuracy $79.3 \%$, sensitivity $70 \%$ and specificity 90\%) (90). However, these data were normalized against miR-16, which is known to be highly dependent on the haemolysis of the sample (90) and was also reported to be altered in MPM $(88,96)$.

Weber et al. took a different approach and analyzed the cell fraction obtained by centrifugation of whole blood; in this fraction miR-103a-3p was downregulated in MPM patients $(N=23)$ compared to asbestos-exposed $(N=$ $17)$ and healthy control subjects $(N=25)$. miR-103a$3 \mathrm{p}$ discriminated MPM patients from asbestos-exposed subjects with a $83 \%$ sensitivity and $71 \%$ specificity, and from healthy controls with $78 \%$ sensitivity and $76 \%$ specificity (91). In a subsequent study the authors confirmed this finding and provided evidence that the association of reduced levels of miR-103a-3p in blood cells with elevated Mesothelin in plasma improved the discrimination of MPM patients $(N=43)$ from asbestosexposed $(N=52)$ individuals (92). However, these findings were not confirmed in a follow-up study of prediagnostic MPM samples (89). In all these studies data were normalized to miR-125a measured in the cell fraction of whole blood.

Cavalleri et al. analyzed the levels of miR-103a-3p along with miR-30e-3p in extracellular vesicles and showed that the 
TABLE 2 | Circulating miRNAs in MPM.

\begin{tabular}{|c|c|c|c|c|c|c|}
\hline miRNAs & $\begin{array}{l}\text { miRNA } \\
\text { expression in } \\
\text { MPM }\end{array}$ & Study design & Samples & $\begin{array}{l}\text { Reference gene, } \\
\text { method of analysis }\end{array}$ & Study results & References \\
\hline miR-126-3p & Reduced & $\begin{array}{l}\mathrm{MPM}=45, \mathrm{HC}=56 \\
\mathrm{NSCLC}=20\end{array}$ & Serum & $\begin{array}{l}\text { Ref gene: RNU6, } \\
\text { cel-miR-39 } \\
\text { Method: TaqMan } \\
\text { microRNA Assay }\end{array}$ & $\begin{array}{l}\text { MPM vs. HC } \\
\text { sensitivity: } 80 \% \text {, } \\
\text { specificity: } 60 \%\end{array}$ & $(86)$ \\
\hline miR-126-3p & Reduced & $\begin{array}{l}\mathrm{MPM}=45, \mathrm{AEXP}=99 \\
\mathrm{HC}=44 \text { (discovery } \\
\text { group); } \\
\mathrm{MPM}=18, \mathrm{AEXP}=50, \\
\mathrm{HC}=20, \mathrm{LC}=42 \\
\text { (validation group); }\end{array}$ & Serum & $\begin{array}{l}\text { Ref gene: RNU6, } \\
\text { cel-miR-39, } \\
\text { Method: TaqMan } \\
\text { MicroRNA Assay } \\
\text { Circulating methylated TM } \\
\text { DNA assay and ELISA }\end{array}$ & $\begin{array}{l}\text { MPM vs. HC } \\
\text { miR-126-3p } \\
\text { sensitivity: } 75 \% \text {, low } \\
\text { specificity: } 54 \% \\
\text { miR-126 + SMRP + } \\
\text { Met-TM: AUC }=0.857\end{array}$ & $(87)$ \\
\hline miR-625-3p & Increased & $\begin{array}{l}\mathrm{MPM}=5, \mathrm{HC}=3 \\
\text { (plasma); } \\
\mathrm{MPM}=15, \mathrm{CS}=14 \\
\text { (plasma); (test cohort) } \\
\mathrm{MPM}=30, \mathrm{AEXP}=10 \\
\text { (serum); (validation cohort) } \\
\mathrm{MPM}=18, \mathrm{CS}= \\
7 \text { (FFPE); }\end{array}$ & $\begin{array}{l}\text { Plasma, } \\
\text { Serum, FFPE } \\
\text { Tissue }\end{array}$ & $\begin{array}{l}\text { Ref gene: miR-16 } \\
\text { (plasma), RNU6B (FFPE) } \\
\text { Method: Human miRNA, } \\
\text { Microarray Agilent; } \\
\text { TaqMan miRNA Assay, } \\
\text { OpenArray Analysis }\end{array}$ & $\begin{array}{l}\text { MPM vs. AEXP test cohort } \\
\text { AUC }=0.824 \\
\text { sensitivity: } 73.33 \% \\
\text { specificity: } 78.57 \% \text { MPM } \\
\text { vs. AEXP validation cohort } \\
\text { AUC }=0.793 \\
\text { sensitivity: } 70 \% \\
\text { specificity: } 90 \%\end{array}$ & (90) \\
\hline miR-103a-3p & Reduced & $\begin{array}{l}M P M=23, A E X P=17 \\
H C=25\end{array}$ & Blood cells & $\begin{array}{l}\text { Ref gene: miR-125a } \\
\text { Method: miRNA } \\
\text { Microarray, TaqMan } \\
\text { miRNA Assay }\end{array}$ & $\begin{array}{l}\text { MPM vs. AEXP AUC = } \\
0.757, \text { cut-off } 0.621 \\
\text { sensitivity: } 83 \% \\
\text { specificity: } 71 \% \text { MPM } \\
\text { vs. HC AUC = } 0.871 \text {, } \\
\text { cut-off } 0.621 \\
\text { sensitivity: } 78 \% \\
\text { specificity: } 76 \%\end{array}$ & (91) \\
\hline
\end{tabular}


TABLE 2 | Continued

\begin{tabular}{|c|c|c|c|c|c|c|}
\hline miRNAs & $\begin{array}{l}\text { miRNA } \\
\text { expression in } \\
\text { MPM }\end{array}$ & Study design & Samples & $\begin{array}{l}\text { Reference gene, } \\
\text { method of analysis }\end{array}$ & Study results & References \\
\hline miR-103a-3p & Reduced & $\mathrm{MPM}=43, \mathrm{AEXP}=52$ & Blood cells & $\begin{array}{l}\text { Ref gene: miR-125a. } \\
\text { Method: TaqMan } \\
\text { miRNA Assay }\end{array}$ & $\begin{array}{l}\text { MPM vs. AEXP } \\
\text { miR-103a-3p: AUC = } \\
\text { 0.76, cut-off } 749.61 \\
\text { sensitivity: } 86 \% \\
\text { specificity: } 63 \% \\
\text { miR-103a-3p + } \\
\text { Mesothelin: } A \cup C=0.90 \text {, } \\
\text { sensitivity: } 86 \% \\
\text { specificity: } 85 \%\end{array}$ & (92) \\
\hline $\begin{array}{l}\text { miR-103a-3p, } \\
\text { miR-30e-3p }\end{array}$ & Reduced & $M P M=23, A E X P=19$ & $\begin{array}{l}\text { Extra-Cellular } \\
\text { Vescicles (EV) }\end{array}$ & $\begin{array}{l}\text { Ref gene: RNU48, } \\
\text { average of miR-99a, } \\
\text { miR-638, miR-720, } \\
\text { miR-1274a. } \\
\text { Method: OpenArray } \\
\text { qRT-PCR, Custom } \\
\text { TaqManTM Low } \\
\text { Density Array }\end{array}$ & $\begin{array}{l}\text { MPM vs. AEXP } \\
\text { miR-103a-3p + } \\
\text { miR-30e-3p: AUC = } \\
0.942 \\
\text { sensitivity: } 95.5 \% \\
\text { specificity: } 80 \%\end{array}$ & (93) \\
\hline miR-2053 & Increased & $\begin{array}{l}M P M=100, A E X P=20 \\
H C=20\end{array}$ & Serum & $\begin{array}{l}\text { Ref gene: RNU6B (serum), } \\
\text { ACTB (RNAs) } \\
\text { Method: miScript SYBR } \\
\text { Green PCR, miScript } \\
\text { Primer Assay }\end{array}$ & $\begin{array}{l}\text { MPM vs. HC } \\
\text { miR-2053: AUC = 0.91, } \\
\text { cut-off 1.25 } \\
\text { sensitivity: } 85 \% \\
\text { specificity: } 97.5 \% \\
\text { miR-2053 + } \\
\text { Inc-RP1-86D1.3 + ARSA } \\
\text { + DRAM1: AUC = 0.94, } \\
\text { sensitivity: } 100 \%, \\
\text { specificity: } 85 \%\end{array}$ & (94) \\
\hline
\end{tabular}

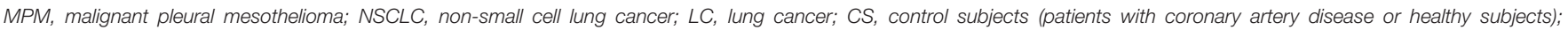

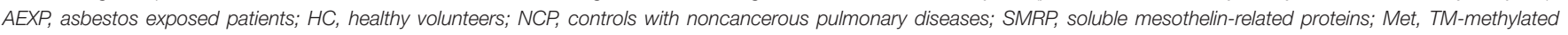
thrombomodulin promoter; adjNCT, adjacent non-cancerous tissue; NMT, non-malignant tissue.

combination of these two markers discriminated MPM patients from asbestos-exposed subjects with a $95.5 \%$ sensitivity and $80 \%$ specificity. These findings were confirmed by normalizing the data to RNU48, miR-99a, miR-638, miR-720, and miR-1274a (93).

A recent study by Matboli et al. (94) detected increased levels of the long non-coding-RNA RP1-86D1.3 and miR-2053 and downregulation of the mRNAs coding for DRAM1 (damageregulated autophagy modulator) and ARSA (arylsulfatase A) in MPM patients $(N=100)$ compared to asbestos-exposed subjects $(N=20)$ and healthy controls $(N=20)$. Data were normalized to RNU6B for miR-2053 and to beta actin for the other RNAs. The function of long non-coding-RP1-86D1.3 is obscure at present, although its expression is frequently altered in lung, breast, colon, and gastric cancer (97, 98). DRAM1 is a p53 responsive gene that encodes a lysosomal membrane protein involved in autophagy (99). ARSA is a lysosomal enzyme that is necessary for the correct function of autophagosomes (100). These mRNAs could be considered as biomarkers of asbestos exposure rather than disease. Moreover, the authors suggest that the upregulation of miR-2053 is a good prognostic marker of MPM, which will be validated in a large sample cohort (94).

\section{CIRCULATING TUMOR DNA (ctDNA)}

ctDNA comprises the fraction of circulating cell-free DNA (cfDNA) that is released by the tumor through apoptosis, necrosis, or active tumor secretion (13). cfDNA is typically found as double-stranded fragments measuring 180-200 base pairs in length, corresponding to nucleosome-associated DNA $(101,102)$. Cancer patients commonly exhibit a higher concentration of cfDNA (103) that contains the mutations found in the tumor.

The detection of ctDNA variants in MPM holds promise as a potential biomarker for the diagnosis and stratification of MPM patients.

Sriram et al. showed that the DNA integrity index (i.e., the ratio between ALU fragments of 247 and $115 \mathrm{bp}$ ) in pleural fluid was higher in MPM patients $(N=16)$ than in benign pleural effusions $(N=23)$ (median: 1.2 vs. 0.8 with $p<0.001$ ) (104). ROC analysis of this cohort revealed that serum Mesothelin had the highest predictive value (AUC: 0.94) followed by pleural fluid Mesothelin (AUC: 0.89) and DNA integrity index in pleural effusion (AUC: 0.82). Using a cut-off of 1.06 for the DNA integrity index, a cut-off of $12.91 \mathrm{nM}$ for pleural fluid Mesothelin and a cut-off of $1.34 \mathrm{nM}$ for serum Mesothelin, the authors obtained a specificity of 
$90 \%$ and a sensitivity of $75 \%$ to distinguish malignant pleural mesothelioma from benign pleural effusion. Further studies are needed to test whether the DNA integrity index in pleural fluid may provide additional information about the progression of disease.

A comprehensive genomic analysis conducted by Bueno et al. on a large cohort of MPM tissue samples revealed mutations in the BAP1, NF2, TP53, SETd2, DDX3X, ULK2, RYR2, CFAP45, SETDB1, and DDX51 genes (105). Using an integrated analysis, these authors identified alterations in the Hippo, mTOR, histone methylation, RNA helicase and p53 signaling pathways.

However, to date none of these mutations have been systematically investigated using a liquid biopsy approach. In a recent study, Hylebos et al. (106) performed whole exome sequencing (WES) of tumor and germline DNAs of ten MPM patients and confirmed the mutation described by Bueno et al. Selected tumor-specific variants of ctDNA were detected in serum samples using ddPCR (Droplet Digital PCR), but the mutation in NF2 was clearly and reproducible detectable in only one patient (fraction of mutated $\mathrm{DNA}=0.8 \%)$.

\section{DNA METHYLATION}

DNA methylation is an epigenetic modification that usually occurs at regions of DNA rich in CpG dinucleotides, which are located mainly in 5' regulatory regions of genes. The DNA methylation pattern may be modified following environment exposure, therapy, aging and disease. Studies have demonstrated that promoter methylation, and alterations of gene expression are a common occurrence in mesothelioma and that the DNA methylation profile in tissue samples was able to distinguish normal pleura from mesothelioma (107). Detection of changes in the methylation profile of ctDNA might thus be a tool for early diagnosis and prognostic stratification of MPM patients (108).

Santarelli et al. (87) evaluated alterations in the methylation of the thrombomodulin (TM) gene in serum in association with serum levels of SMRP and miR-126 in MPM patients $(N=45)$, asbestos-exposed healthy subjects $(N=99)$, and healthy donors $(N=44)$. The model based on the combination of these 3 parameters improved the differential diagnosis of MPM, with an AUC of 0.857. A significant risk of disease (odds ratio $>4$ ) was found in the presence of high levels of SMRP in association with altered levels of either miR-126 or TM promoter methylation, and when both miR-126 and TM promoter methylation were altered even at low SMRP concentration. It will be interesting to test the validity of these findings in large prospective longitudinal cohorts $(87,109)$.

In a very recent study, Guarrera et al. (110) investigated peripheral blood DNA methylation as a biomarker of MPM in a large cohort of patients and controls. Results showed a distinct methylation signature in MPM patients compared to controls, with more than 800 differentially methylated
(DM) CpG sites and significant enrichment for genes controlling innate immunity and neutrophil degranulation. The authors identified seven top DM-CpGs, three of which were hypomethylated (FOXK1, MYB, and TAF4) and four hypermethylated (CXCR6/FYCO1, TAP1, MORC2, and LIME1). ROC analysis showed a diagnostic value of the methylation levels of the seven top DM-CpGs in association with age, sex and asbestos exposure levels (AUC: 0.89). Univariate regression analysis showed no clear evidence for differences in the seven DM-CpGs among the different histotypes of mesothelioma. Overall, the results obtained in these studies are very promising but need to be validated in a longitudinal study.

\section{CIRCULATING TUMOR CELLS (CTCs)}

CTCs are intact tumor cells derived from primary or metastatic tumor sites. The number of CTCs present in the blood is very low at early stages and increases in advanced stages of cancer (111).

To date, CELLSEARCH ${ }^{\circledR}$ is the only FDA-approved test for capturing and counting CTCs. This method consists of magnetic particles coated with antibodies targeting the Epithelial Cell Adhesion Molecule (EpCAM), an antigen present on most epithelial tumor cells (112).

For MPM, which originates from the mesothelium, the CELLSEARCH technique has demonstrated a very low diagnostic sensitivity (113-115).

More recently, Chikaishi et al. developed a "CTC-chip" that was able to capture the Ep-Cam negative CTCs by targeting podoplanin (116), a mucine-type transmembrane glycoprotein whose expression is increased in malignant cells of mesothelial origin (117). Yoneda et al. (118) evaluated CTCs in a small cohort of 16 MPM patients using the CellSearch and CTC-chip techniques. The CTC-chip performed better than CellSearch, and demonstrated a significant diagnostic value in discriminating between early and advanced disease $(\mathrm{AUC}=0.851)$.

\section{CONCLUSIONS AND PERSPECTIVES}

At present, there is no reliable marker for the longitudinal monitoring and risk assessment of asbestos-exposed individuals. Although liquid biopsy is still far to replace tissue biopsy for MPM diagnosis, it holds great promise for non-invasive tracking of the follow-up of asbestos-exposed individuals. Plasma and serum samples represent minimally invasive, low risk, and easily obtained biological fluids and many studies have indicated potentially interesting biomarkers, including Mesothelin (early diagnosis and prognostic stratification of MPM), Osteopontin (early diagnosis), Fibulin-3 (early diagnosis), HMGB1 (early diagnosis), VEGF (early diagnosis and prognostic stratification) and miRNAs (early diagnosis). More recent studies have also suggested that markers of oxidative stress, CTCs and ctDNA might also be useful for the screening/early diagnosis of 
MPM. Furthermore, a study by Zucali et al. demonstrated that TS (Thymidylate Synthase) is overexpressed in MPM tissues and is a strong predictor of responsiveness of MPM patients to Pemetrexed/Carboplatin (119). It is thus possible that detection of TS in circulating MPM cells or as circulating cell-free RNA might prove to be an interesting predictive biomarker $(120,121)$.

However, most of these markers were studied in restricted patients' cohorts, and the conclusive identification of robust circulating biomarkers for early diagnosis and prognostic stratification of MPM patients awaits validation in large prospective studies. Furthermore, most of these studies were highly heterogeneous in terms of preanalytical and analytical protocols employed. Therefore, future efforts should be focused on reaching a consensus on the standardization and normalization of the different assays to achieve robust and reproducible results. Multivariate analyses of multiple biomarkers may also improve the diagnostic power of these assays.

\section{REFERENCES}

1. Robinson BM. Malignant pleural mesothelioma: an epidemiological perspective. Ann Cardiothorac Surg. (2012) 1:491-6. doi: 10.3978/j.issn.2225-319X.2012.11.04

2. Delgermaa V, Takahashi K, Park EK, Le GV, Hara T, Sorahan T. Global mesothelioma deaths reported to the World Health Organization between 1994 and 2008. Bull World Health Organ. (2011) 89, 716-24, 724a-c. doi: $10.2471 /$ blt.11.086678

3. Vogelzang NJ, Rusthoven JJ, Symanowski J, Denham C, Kaukel E, Ruffie P, et al. Phase III study of pemetrexed in combination with cisplatin versus cisplatin alone in patients with malignant pleural mesothelioma. J Clin Oncol. (2003) 21:2636-44. doi: 10.1200/jco.2003.11.136

4. Virta RL. Worldwide asbestos supply and consumption trends from 1900 through 2003. Circular. (2006) 1298. doi: 10.3133/cir1298

5. Carbone M, Yang H. Molecular pathways: targeting mechanisms of asbestos and erionite carcinogenesis in mesothelioma. Clin Cancer Res. (2012) 18:598-604. doi: 10.1158/1078-0432.ccr-11-2259

6. Bograd AJ, Suzuki K, Vertes E, Colovos C, Morales EA, Sadelain M, et al. Immune responses and immunotherapeutic interventions in malignant pleural mesothelioma. Cancer Immunol Immunother. (2011) 60:1509-27. doi: 10.1007/s00262-011-1103-6

7. Chalmers ZR, Connelly CF, Fabrizio D, Gay L, Ali SM, Ennis R, et al. Analysis of 100,000 human cancer genomes reveals the landscape of tumor mutational burden. Genome Med. (2017) 9:34. doi: 10.1186/s13073-017-0424-2

8. Bott M, Brevet M, Taylor BS, Shimizu S, Ito T, Wang L, et al. The nuclear deubiquitinase BAP1 is commonly inactivated by somatic mutations and 3p21.1 losses in malignant pleural mesothelioma. Nat Genet. (2011) 43:66872. doi: $10.1038 / \mathrm{ng} .855$

9. Di Meo A, Bartlett J, Cheng Y, Pasic MD, Yousef GM. Liquid biopsy: a step forward towards precision medicine in urologic malignancies. Mol Cancer. (2017) 16:80. doi: 10.1186/s12943-017-0644-5

10. Diaz LA Jr, Bardelli A. Liquid biopsies: genotyping circulating tumor DNA. J Clin Oncol. (2014) 32:579-86. doi: 10.1200/jco.2012.45.2011

11. Galateau-Salle F, Churg A, Roggli V, Travis WD. The 2015 World Health Organization classification of tumors of the pleura: advances since the 2004 classification. J Thorac Oncol. (2016) 11:142-54. doi: $10.1016 /$ j.jtho.2015.11.005

12. Johnen G, Burek K, Raiko I, Wichert K, Pesch B, Weber DG, et al. Prediagnostic detection of mesothelioma by circulating calretinin and mesothelin - a case-control comparison nested into a prospective

\section{AUTHOR CONTRIBUTIONS}

IC prepared the paragraphs on ctDNA, DNA methylation, CTC, and revised the final version of the paper. LU prepared the paragraph on Circulating Tumor Proteins and revised the final version of the paper. ES prepared the paragraph on Circulating miRNAs and revised the final version of the paper. GP prepared the Introduction and revised the final version of the paper. VC prepared the paragraphs on Oxidative Stress Markers, on Perspectives, and revised the final version of the paper.

\section{FUNDING}

This work was supported by $5 \mathrm{X} 1000$ funds of the Istituto Oncologico Veneto IOV-IRCCS and by a grant by the Italian Association for Cancer Research (AIRC IG17794).

\section{ACKNOWLEDGMENTS}

We thank Dr. DM D’Agostino for discussions.

cohort of asbestos-exposed workers. Sci Rep. (2018) 8:14321. doi: 10.1038/s41598-018-32315-3

13. De Rubis G, Rajeev Krishnan S, Bebawy M. Liquid biopsies in cancer diagnosis, monitoring, and prognosis. Trends Pharmacol Sci. (2019) 40:17286. doi: 10.1016/j.tips.2019.01.006

14. Bettegowda C, Sausen M, Leary RJ, Kinde I, Wang Y, Agrawal $\mathrm{N}$, et al. Detection of circulating tumor DNA in early- and latestage human malignancies. Sci Transl Med. (2014) 6:224ra24. doi: $10.1126 /$ scitranslmed.3007094

15. Pastan I, Hassan R. Discovery of mesothelin and exploiting it as a target for immunotherapy. Cancer Res. (2014) 74:2907-12. doi: 10.1158/0008-5472.can-14-0337

16. Forest F, Patoir A, Dal Col P, Sulaiman A, Camy F, Laville D, et al. Nuclear grading, BAP1, mesothelin and PD-L1 expression in malignant pleural mesothelioma: prognostic implications. Pathology. (2018) 50:635-41. doi: 10.1016/j.pathol.2018.05.002

17. Scholler N, Fu N, Yang Y, Ye Z, Goodman GE, Hellstrom KE, et al. Soluble member(s) of the mesothelin/megakaryocyte potentiating factor family are detectable in sera from patients with ovarian carcinoma. Proc Natl Acad Sci USA. (1999) 96:11531-6. doi: 10.1073/pnas.96.20. 11531

18. Hollevoet K, Reitsma JB, Creaney J, Grigoriu BD, Robinson BW, Scherpereel $A$, et al. Serum mesothelin for diagnosing malignant pleural mesothelioma: an individual patient data meta-analysis. J Clin Oncol. (2012) 30:1541-9. doi: 10.1200/jco.2011.39.6671

19. Rai AJ, Flores RM, Mathew A, Gonzalez-Espinoza R, Bott M, Ladanyi M, et al. Soluble mesothelin related peptides (SMRP) and osteopontin as protein biomarkers for malignant mesothelioma: analytical validation of ELISA based assays and characterization at mRNA and protein levels. Clin Chem Lab Med. (2010) 48:271-8. doi: 10.1515/cclm.2010.066

20. Beyer HL, Geschwindt RD, Glover CL, Tran L, Hellstrom I, Hellstrom KE, et al. A potential test for malignant pleural mesothelioma. Clin Chem. (2007) 53:666-72. doi: 10.1373/clinchem.2006.079327

21. Ordonez NG. Value of mesothelin immunostaining in the diagnosis of mesothelioma. Mod Pathol. (2003) 16:192-7. doi: 10.1097/01.mp.0000056981.16578.c3

22. Robinson BW, Creaney J, Lake R, Nowak A, Musk AW, de Klerk N, et al. Mesothelin-family proteins and diagnosis of mesothelioma. Lancet. (2003) 362:1612-6. doi: 10.1016/s0140-6736(03)14794-0

23. Scherpereel A, Grigoriu B, Conti M, Gey T, Gregoire M, Copin MC, et al. Soluble mesothelin-related peptides in the diagnosis of malignant 
pleural mesothelioma. Am J Respir Crit Care Med. (2006) 173:1155-60. doi: 10.1164/rccm.200511-1789OC

24. Cristaudo A, Foddis R, Vivaldi A, Guglielmi G, Dipalma N, Filiberti $\mathrm{R}$, et al. Clinical significance of serum mesothelin in patients with mesothelioma and lung cancer. Clin Cancer Res. (2007) 13:5076-81. doi: 10.1158/1078-0432.ccr-07-0629

25. Grigoriu BD, Scherpereel A, Devos P, Chahine B, Letourneux M, Lebailly $\mathrm{P}$, et al. Utility of osteopontin and serum mesothelin in malignant pleural mesothelioma diagnosis and prognosis assessment. Clin Cancer Res. (2007) 13:2928-35. doi: 10.1158/1078-0432.ccr-06-2144

26. Pass HI, Wali A, Tang N, Ivanova A, Ivanov S, Harbut M, et al. Soluble mesothelin-related peptide level elevation in mesothelioma serum and pleural effusions. Ann Thorac Surg. (2008) 85:265-72; discussion 272. doi: 10.1016/j.athoracsur.2007.07.042

27. Rodriguez Portal JA, Rodriguez Becerra E, Rodriguez Rodriguez D, Alfageme Michavila I, Quero Martinez A, Diego Roza C, et al. Serum levels of soluble mesothelin-related peptides in malignant and nonmalignant asbestos-related pleural disease: relation with past asbestos exposure. Cancer Epidemiol Biomarkers Prev. (2009) 18:646-50. doi: 10.1158/1055-9965.epi-08-0422

28. Bayram M, Dongel I, Akbas A, Benli I, Akkoyunlu ME, Bakan ND. Serum biomarkers in patients with mesothelioma and pleural plaques and healthy subjects exposed to naturally occurring asbestos. Lung. (2014) 192:197-203. doi: $10.1007 / \mathrm{s} 00408-013-9526-9$

29. Pass HI, Lott D, Lonardo F, Harbut M, Liu Z, Tang N, et al. Asbestos exposure, pleural mesothelioma, and serum osteopontin levels. N Engl J Med. (2005) 353:1564-73. doi: 10.1056/NEJMoa051185

30. Cristaudo A, Bonotti A, Simonini S, Vivaldi A, Guglielmi G, Ambrosino N, et al. Combined serum mesothelin and plasma osteopontin measurements in malignant pleural mesothelioma. J Thorac Oncol. (2011) 6:1587-93. doi: 10.1097/JTO.0b013e31821e1c08

31. Creaney J, Yeoman D, Musk AW, de Klerk N, Skates SJ, Robinson BW. Plasma versus serum levels of osteopontin and mesothelin in patients with malignant mesothelioma-which is best? Lung Cancer. (2011) 74:55-60. doi: 10.1016/j.lungcan.2011.02.007

32. Pass HI, Levin SM, Harbut MR, Melamed J, Chiriboga L, Donington J, et al. Fibulin-3 as a blood and effusion biomarker for pleural mesothelioma. $N$ Engl J Med. (2012) 367:1417-27. doi: 10.1056/NEJMoa1115050

33. Kirschner MB, Pulford E, Hoda MA, Rozsas A, Griggs K, Cheng YY, et al. Fibulin-3 levels in malignant pleural mesothelioma are associated with prognosis but not diagnosis. Br J Cancer. (2015) 113:963-9. doi: $10.1038 /$ bjc. 2015.286

34. Creaney J, Dick IM, Robinson BW. Comparison of mesothelin and fibulin3 in pleural fluid and serum as markers in malignant mesothelioma. Curr Opin Pulm Med. (2015) 21:352-6. doi: 10.1097/mcp.00000000 00000167

35. Napolitano A, Antoine DJ, Pellegrini L, Baumann F, Pagano I, Pastorino S, et al. HMGB1 and its hyperacetylated isoform are sensitive and specific serum biomarkers to detect asbestos exposure and to identify mesothelioma patients. Clin Cancer Res. (2016) 22:3087-96. doi: 10.1158/1078-0432.ccr-15-1130

36. Lamote K, Baas P, van Meerbeeck JP. Fibulin-3 as a biomarker for pleural mesothelioma. N Engl J Med. (2013) 368:189-90.

37. Creaney J, Olsen NJ, Brims F, Dick IM, Musk AW, de Klerk NH, et al. Serum mesothelin for early detection of asbestos-induced cancer malignant mesothelioma. Cancer Epidemiol Biomarkers Prev. (2010) 19:2238-46. doi: 10.1158/1055-9965.epi-10-0346

38. Park EK, Thomas PS, Creaney J, Johnson AR, Robinson BW, Yates DH. Factors affecting soluble mesothelin related protein levels in an asbestos-exposed population. Clin Chem Lab Med. (2010) 48:869-74. doi: $10.1515 / \mathrm{cclm} .2010 .165$

39. Shiomi K, Shiomi S, Ishinaga Y, Sakuraba M, Hagiwara Y, Miyashita K, et al. Impact of renal failure on the tumor markers of mesothelioma, N-ERC/mesothelin and osteopontin. Anticancer Res. (2011) 31:1427-30.

40. Hollevoet K, Van Cleemput J, Thimpont J, De Vuyst P, Bosquee L, Nackaerts $\mathrm{K}$, et al. Serial measurements of mesothelioma serum biomarkers in asbestosexposed individuals: a prospective longitudinal cohort study. J Thorac Oncol. (2011) 6:889-95. doi: 10.1097/JTO.0b013e31820db377
41. Robinson BW, Creaney J, Lake R, Nowak A, Musk AW, de Klerk N, et al. Soluble mesothelin-related protein-a blood test for mesothelioma. Lung Cancer. (2005) 49(Suppl. 1):S109-11. doi: 10.1016/j.lungcan.2005. 03.020

42. Creaney J, van Bruggen I, Hof M, Segal A, Musk AW, de Klerk N, et al. Combined CA125 and mesothelin levels for the diagnosis of malignant mesothelioma. Chest. (2007) 132:1239-46. doi: 10.1378/chest.07-0013

43. Schneider J, Hoffmann H, Dienemann H, Herth FJ, Meister M, Muley T. Diagnostic and prognostic value of soluble mesothelin-related proteins in patients with malignant pleural mesothelioma in comparison with benign asbestosis and lung cancer. J Thorac Oncol. (2008) 3:1317-24. doi: 10.1097/JTO.0b013e318187491c

44. Creaney J, Francis RJ, Dick IM, Musk AW, Robinson BW, Byrne $\mathrm{MJ}$, et al. Serum soluble mesothelin concentrations in malignant pleural mesothelioma: relationship to tumor volume, clinical stage and changes in tumor burden. Clin Cancer Res. (2011) 17:1181-9. doi: 10.1158/1078-0432.ccr-10-1929

45. Wheatley-Price P, Yang B, Patsios D, Patel D, Ma C, Xu W, et al. Soluble mesothelin-related Peptide and osteopontin as markers of response in malignant mesothelioma. J Clin Oncol. (2010) 28:3316-22. doi: 10.1200/jco.2009.26.9944

46. Onda M, Nagata S, Ho M, Bera TK, Hassan R, Alexander RH, et al. Megakaryocyte potentiation factor cleaved from mesothelin precursor is a useful tumor marker in the serum of patients with mesothelioma. Clin Cancer Res. (2006) 12:4225-31. doi: 10.1158/1078-0432.ccr-06-0472

47. Hassan R, Sharon E, Thomas A, Zhang J, Ling A, Miettinen M, et al. Phase 1 study of the antimesothelin immunotoxin SS1P in combination with pemetrexed and cisplatin for front-line therapy of pleural mesothelioma and correlation of tumor response with serum mesothelin, megakaryocyte potentiating factor, and cancer antigen 125. Cancer. (2014) 120:3311-9. doi: $10.1002 / \mathrm{cncr} .28875$

48. Hassan R, Miller AC, Sharon E, Thomas A, Reynolds JC, Ling A, et al. Major cancer regressions in mesothelioma after treatment with an anti-mesothelin immunotoxin and immune suppression. Sci Transl Med. (2013) 5:208ra147. doi: 10.1126/scitranslmed.3006941

49. Cao L, Yu Y, Thomas A, Zhang J, Onda M, Meltzer P, et al. Megakaryocyte potentiating factor as a predictive biomarker for therapies against malignant mesothelioma. JCO Precis Oncol. (2018) doi: 10.1200/po.17.00282

50. Coppola D, Szabo M, Boulware D, Muraca P, Alsarraj M, Chambers AF, et al. Correlation of osteopontin protein expression and pathological stage across a wide variety of tumor histologies. Clin Cancer Res. (2004) 10:184-90. doi: 10.1158/1078-0432.CCR-1405-2

51. Foddis R, Bonotti A, Landi S, Fallahi P, Guglielmi G, Cristaudo A. Biomarkers in the prevention and follow-up of workers exposed to asbestos. J Thorac Dis. (2018) 10:S360-8. doi: 10.21037/jtd.2017.12.17

52. Hollevoet K, Nackaerts K, Gosselin R, De Wever W, Bosquee L, De Vuyst $\mathrm{P}$, et al. Soluble mesothelin, megakaryocyte potentiating factor, and osteopontin as markers of patient response and outcome in mesothelioma. J Thorac Oncol. (2011) 6:1930-7. doi: 10.1097/JTO.0b013e31822 72294

53. Pass HI, Goparaju C. Fibulin-3 as a biomarker for pleural mesothelioma. $N$ Engl J Med. (2013) 368:189-90. doi: 10.1056/NEJMc1213514

54. Creaney J, Dick IM, Meniawy TM, Leong SL, Leon JS, Demelker Y, et al. Comparison of fibulin-3 and mesothelin as markers in malignant mesothelioma. Thorax. (2014) 69:895-902. doi: 10.1136/thoraxinl-2014-205205

55. Sanchez VC, Pietruska JR, Miselis NR, Hurt RH, Kane AB. Biopersistence and potential adverse health impacts of fibrous nanomaterials: what have we learned from asbestos? Wiley Interdiscip Rev Nanomed Nanobiotechnol. (2009) 1:511-29. doi: 10.1002/wnan.41

56. Ono M. Molecular links between tumor angiogenesis and inflammation: inflammatory stimuli of macrophages and cancer cells as targets for therapeutic strategy. Cancer Sci. (2008) 99:1501-6. doi: 10.1111/j.1349-7006.2008.00853.x

57. Pinato DJ, Mauri FA, Ramakrishnan R, Wahab L, Lloyd T, Sharma R. Inflammation-based prognostic indices in malignant pleural mesothelioma. J Thorac Oncol. (2012) 7:587-94. doi: 10.1097/JTO.0b013e31823f45c1 
58. Kao SC, Pavlakis N, Harvie R, Vardy JL, Boyer MJ, van Zandwijk N, et al. High blood neutrophil-to-lymphocyte ratio is an indicator of poor prognosis in malignant mesothelioma patients undergoing systemic therapy. Clin Cancer Res. (2010) 16:5805-13. doi: 10.1158/1078-0432.ccr-10-2245

59. Chen N, Liu S, Huang L, Li W, Yang W, Cong T, et al. Prognostic significance of neutrophil-to-lymphocyte ratio in patients with malignant pleural mesothelioma: a meta-analysis. Oncotarget. (2017) 8:57460-9. doi: 10.18632/oncotarget.15404

60. Bianchi ME. DAMPs, PAMPs and alarmins: all we need to know about danger. J Leukoc Biol. (2007) 81:1-5. doi: 10.1189/jlb.0306164

61. Jube S, Rivera ZS, Bianchi ME, Powers A, Wang E, Pagano I, et al. Cancer cell secretion of the DAMP protein HMGB1 supports progression in malignant mesothelioma. Cancer Res. (2012) 72:3290-301. doi: 10.1158/0008-5472.can-11-3481

62. Venereau E, Ceriotti C, Bianchi ME. DAMPs from cell death to New Life. Front Immunol. (2015) 6:422. doi: 10.3389/fimmu.2015.00422

63. Kumar-Singh S, Weyler J, Martin MJ, Vermeulen PB, Van Marck E. Angiogenic cytokines in mesothelioma: a study of VEGF, FGF1 and-2, and TGF beta expression. J Pathol. (1999) 189:72-8. doi: 10.1002/(sici)1096-9896(199909)189:1<72::aid-path401>3.0.co;2-0

64. Strizzi L, Catalano A, Vianale G, Orecchia S, Casalini A, Tassi G, et al. Vascular endothelial growth factor is an autocrine growth factor in human malignant mesothelioma. J Pathol. (2001) 193:468-75. doi: 10.1002/path.824

65. Demirag F, Unsal E, Yilmaz A, Caglar A. Prognostic significance of vascular endothelial growth factor, tumor necrosis, and mitotic activity index in malignant pleural mesothelioma. Chest. (2005) 128:3382-7. doi: 10.1378/chest.128.5.3382

66. Hirayama N, Tabata C, Tabata R, Maeda R, Yasumitsu A, Yamada $\mathrm{S}$, et al. Pleural effusion VEGF levels as a prognostic factor of malignant pleural mesothelioma. Respir Med. (2011) 105:137-42. doi: 10.1016/j.rmed.2010.10.010

67. Yasumitsu A, Tabata C, Tabata R, Hirayama N, Murakami A, Yamada $\mathrm{S}$, et al. Clinical significance of serum vascular endothelial growth factor in malignant pleural mesothelioma. J Thorac Oncol. (2010) 5:479-83. doi: 10.1097/JTO.0b013e3181d2f008

68. Nowak AK, Millward MJ, Creaney J, Francis RJ, Dick IM, Hasani A, et al. A phase II study of intermittent sunitinib malate as second-line therapy in progressive malignant pleural mesothelioma. J Thorac Oncol. (2012) 7:1449-56. doi: 10.1097/JTO.0b013e31825f22ee

69. Kao SC, Harvie R, Paturi F, Taylor R, Davey R, Abraham R, et al. The predictive role of serum VEGF in an advanced malignant mesothelioma patient cohort treated with thalidomide alone or combined with cisplatin/gemcitabine. Lung Cancer. (2012) 75:248-54. doi: 10.1016/j.lungcan.2011.06.007

70. Werther K, Christensen IJ, Nielsen HJ. Determination of vascular endothelial growth factor (VEGF) in circulating blood: significance of VEGF in various leucocytes and platelets. Scand J Clin Lab Invest. (2002) 62:343-50. doi: 10.1080/00365510260296492

71. Bille A, Krug LM, Woo KM, Rusch VW, Zauderer MG. Contemporary analysis of prognostic factors in patients with unresectable malignant pleural mesothelioma. J Thorac Oncol. (2016) 11:249-55. doi: 10.1016/j.jtho.2015.10.003

72. Shukla A, Gulumian M, Hei TK, Kamp D, Rahman Q, Mossman BT. Multiple roles of oxidants in the pathogenesis of asbestos-induced diseases. Free Radic Biol Med. (2003) 34:1117-29.

73. Hardy JA, Aust AE. The effect of iron binding on the ability of crocidolite asbestos to catalyze DNA single-strand breaks. Carcinogenesis. (1995) 16:319-25. doi: 10.1093/carcin/16.2.319

74. Eberhardt MK, Roman-Franco AA, Quiles MR. Asbestos-induced decomposition of hydrogen peroxide. Environ Res. (1985) 37:287-92.

75. Pascolo L, Gianoncelli A, Schneider G, Salome M, Schneider M, Calligaro $\mathrm{C}$, et al. The interaction of asbestos and iron in lung tissue revealed by synchrotron-based scanning X-ray microscopy. Sci Rep. (2013) 3:1123. doi: $10.1038 /$ srep01123

76. Ghio AJ, Stonehuerner J, Richards J, Devlin RB. Iron homeostasis in the lung following asbestos exposure. Antioxid Redox Signal. (2008) 10:371-7. doi: 10.1089/ars.2007.1909
77. Lewis BP, Burge CB, Bartel DP. Conserved seed pairing, often flanked by adenosines, indicates that thousands of human genes are microRNA targets. Cell. (2005) 120:15-20. doi: 10.1016/j.cell.2004.12.035

78. Reid G. MicroRNAs in mesothelioma: from tumour suppressors and biomarkers to therapeutic targets. J Thorac Dis. (2015) 7:1031-40. doi: 10.3978/j.issn.2072-1439.2015.04.56

79. Li MH, Fu SB, Xiao HS. Genome-wide analysis of microRNA and mRNA expression signatures in cancer. Acta Pharmacol Sin. (2015) 36:1200-11. doi: 10.1038/aps.2015.67

80. Schwarzenbach H, Nishida N, Calin GA, Pantel K. Clinical relevance of circulating cell-free microRNAs in cancer. Nat Rev Clin Oncol. (2014) 11:145-56. doi: 10.1038/nrclinonc.2014.5

81. Turchinovich A, Weiz L, Burwinkel B. Isolation of circulating microRNA associated with RNA-binding protein. Methods Mol Biol. (2013) 1024:97107. doi: 10.1007/978-1-62703-453-1_8

82. Boeri M, Verri C, Conte D, Roz L, Modena P, Facchinetti F, et al. MicroRNA signatures in tissues and plasma predict development and prognosis of computed tomography detected lung cancer. Proc Natl Acad Sci USA. (2011) 108:3713-8. doi: 10.1073/pnas.1100048108

83. Sharova E, Grassi A, Marcer A, Ruggero K, Pinto F, Bassi P, et al. A circulating miRNA assay as a first-line test for prostate cancer screening. Br J Cancer. (2016) 114:1362-6. doi: 10.1038/bjc.2016.151

84. Ledda C, Senia P, Rapisarda V. Biomarkers for early diagnosis and prognosis of malignant pleural mesothelioma: the quest goes on. Cancers. (2018) 10:203. doi: 10.3390/cancers 10060203

85. Santarelli L, Strafella E, Staffolani S, Amati M, Emanuelli M, Sartini D, et al. Association of MiR-126 with soluble mesothelin-related peptides, a marker for malignant mesothelioma. PLoS ONE. (2011) 6:e18232. doi: 10.1371/journal.pone.0018232

86. Tomasetti M, Staffolani S, Nocchi L, Neuzil J, Strafella E, Manzella $\mathrm{N}$, et al. Clinical significance of circulating miR-126 quantification in malignant mesothelioma patients. Clin Biochem. (2012) 45:575-81. doi: 10.1016/j.clinbiochem.2012.02.009

87. Santarelli L, Staffolani S, Strafella E, Nocchi L, Manzella N, Grossi P, et al. Combined circulating epigenetic markers to improve mesothelin performance in the diagnosis of malignant mesothelioma. Lung Cancer. (2015) 90:457-64. doi: 10.1016/j.lungcan.2015.09.021

88. Mozzoni P, Ampollini L, Goldoni M, Alinovi R, Tiseo M, Gnetti L, et al. MicroRNA expression in malignant pleural mesothelioma and asbestosis: a pilot study. Dis Markers. (2017) 2017:9645940. doi: 10.1155/2017/9645940

89. Weber DG, Brik A, Casjens S, Burek K, Lehnert M, Pesch B, et al. Are circulating microRNAs suitable for the early detection of malignant mesothelioma? Results from a nested case-control study. BMC Res Notes. (2019) 12:77. doi: 10.1186/s13104-019-4113-7

90. Kirschner MB, Cheng YY, Badrian B, Kao SC, Creaney J, Edelman JJ, et al. Increased circulating miR-625-3p: a potential biomarker for patients with malignant pleural mesothelioma. J Thorac Oncol. (2012) 7:1184-91. doi: 10.1097/JTO.0b013e3182572e83

91. Weber DG, Johnen G, Bryk O, Jockel KH, Bruning T. Identification of miRNA-103 in the cellular fraction of human peripheral blood as a potential biomarker for malignant mesothelioma-a pilot study. PLoS ONE. (2012) 7:e30221. doi: 10.1371/journal.pone.0030221

92. Weber DG, Casjens S, Johnen G, Bryk O, Raiko I, Pesch B, et al. Combination of MiR-103a-3p and mesothelin improves the biomarker performance of malignant mesothelioma diagnosis. PLoS ONE. (2014) 9:e114483. doi: 10.1371/journal.pone.0114483

93. Cavalleri T, Angelici L, Favero C, Dioni L, Mensi C, Bareggi C, et al. Plasmatic extracellular vesicle microRNAs in malignant pleural mesothelioma and asbestos-exposed subjects suggest a 2-miRNA signature as potential biomarker of disease. PLOS ONE. (2017) 12:e0176680. doi: 10.1371/journal.pone.0176680

94. Matboli M, Shafei AE, Ali MA, Gaber AI, Galal A, Tarek O, et al. Clinical significance of serum DRAM1 mRNA, ARSA mRNA, hsa-miR-2053 and lncRNA-RP1-86D1.3 axis expression in malignant pleural mesothelioma. $J$ Cell Biochem. (2019) 120:3203-11. doi: 10.1002/jcb.27586

95. Benz F, Roderburg C, Vargas Cardenas D, Vucur M, Gautheron J, Koch A, et al. U6 is unsuitable for normalization of serum miRNA levels 
in patients with sepsis or liver fibrosis. Exp Mol Med. (2013) 45:e42. doi: 10.1038/emm.2013.81

96. Reid G, Pel ME, Kirschner MB, Cheng YY, Mugridge N, Weiss J, et al. Restoring expression of miR-16: a novel approach to therapy for malignant pleural mesothelioma. Ann Oncol. (2013) 24:3128-35. doi: 10.1093/annonc/mdt412

97. Liu J, Wang J, Song Y, Yang Y, Hu Y, Gao P, et al. A potential biomarker for colorectal cancer: long non-coding RNA RP1-13P20.6. Neoplasma. (2016) 63:984-90. doi: 10.4149/neo_2016_618

98. Hu AX, Huang ZY, Zhang L, Shen J. Potential prognostic long noncoding RNA identification and their validation in predicting survival of patients with multiple myeloma. Tumour Biol. (2017) 39:1010428317694563. doi: $10.1177 / 1010428317694563$

99. Crighton D, Wilkinson S, O'Prey J, Syed N, Smith P, Harrison PR, et al. DRAM, a p53-induced modulator of autophagy, is critical for apoptosis. Cell. (2006) 126:121-34. doi: 10.1016/j.cell.2006.05.034

100. Zerah M, Piguet F, Colle MA, Raoul S, Deschamps JY, Deniaud J, et al. Intracerebral gene therapy using AAVrh.10-hARSA recombinant vector to treat patients with early-onset forms of metachromatic leukodystrophy: preclinical feasibility and safety assessments in nonhuman primates. Hum Gene Ther Clin Dev. (2015) 26:113-24. doi: 10.1089/humc. 2014.139

101. Fan HC, Blumenfeld YJ, Chitkara U, Hudgins L, Quake SR. Analysis of the size distributions of fetal and maternal cell-free DNA by paired-end sequencing. Clin Chem. (2010) 56:1279-86. doi: 10.1373/clinchem.2010.144188

102. Corcoran RB, Chabner BA. Application of cell-free DNA analysis to cancer treatment. N Engl J Med. (2018) 379:1754-65. doi: 10.1056/NEJMra1706174

103. Leon SA, Shapiro B, Sklaroff DM, Yaros MJ. Free DNA in the serum of cancer patients and the effect of therapy. Cancer Res. (1977) 37:646-50.

104. Sriram KB, Relan V, Clarke BE, Duhig EE, Windsor MN, Matar KS, et al. Pleural fluid cell-free DNA integrity index to identify cytologically negative malignant pleural effusions including mesotheliomas. BMC Cancer. (2012) 12:428. doi: 10.1186/1471-2407-12-428

105. Bueno R, Stawiski EW, Goldstein LD, Durinck S, De Rienzo A, Modrusan Z, et al. Comprehensive genomic analysis of malignant pleural mesothelioma identifies recurrent mutations, gene fusions and splicing alterations. Nat Genet. (2016) 48:407-16. doi: 10.1038/ng.3520

106. Hylebos M, Op de Beeck K, Pauwels P, Zwaenepoel K, van Meerbeeck JP, Van Camp G. Tumor-specific genetic variants can be detected in circulating cellfree DNA of malignant pleural mesothelioma patients. Lung Cancer. (2018) 124:19-22. doi: 10.1016/j.lungcan.2018.07.028

107. Vandermeers F, Neelature Sriramareddy S, Costa C, Hubaux R, Cosse JP, Willems L. The role of epigenetics in malignant pleural mesothelioma. Lung Cancer. (2013) 81:311-8. doi: 10.1016/j.lungcan. 2013.05.014

108. Kanherkar RR, Bhatia-Dey N, Csoka AB. Epigenetics across the human lifespan. Front Cell Dev Biol. (2014) 2:49. doi: 10.3389/fcell.2014.00049

109. Tomasetti M, Amati M, Neuzil J, Santarelli L. Circulating epigenetic biomarkers in lung malignancies: From early diagnosis to therapy. Lung Cancer. (2017) 107:65-72. doi: 10.1016/j.lungcan.2016.05.023

110. Guarrera S, Viberti C, Cugliari G, Allione A, Casalone E, Betti M, et al. Peripheral blood DNA methylation as potential biomarker of malignant pleural mesothelioma in asbestos-exposed subjects. J Thorac Oncol. (2019) 14:527-39. doi: 10.1016/j.jtho.2018.10.163
111. Young R, Pailler E, Billiot F, Drusch F, Barthelemy A, Oulhen M, et al. Circulating tumor cells in lung cancer. Acta Cytol. (2012) 56:655-60. doi: $10.1159 / 000345182$

112. Su DW, Nieva J. Biophysical technologies for understanding circulating tumor cell biology and metastasis. Transl Lung Cancer Res. (2017) 6:473-85. doi: 10.21037/tlcr.2017.05.08

113. Pinton G, Manente AG, Moro L, Mutti L. Circulating tumor cells as a diagnostic test for malignant pleural mesothelioma. Expert Opin Med Diagn. (2012) 6:171-3. doi: 10.1517/17530059.2012.676042

114. Raphael J, Massard C, Gong IY, Farace F, Margery J, Billiot F, et al. Detection of circulating tumour cells in peripheral blood of patients with malignant pleural mesothelioma. Cancer Biomark. (2015) 15:151-6. doi: $10.3233 / \mathrm{cbm}-140448$

115. Yoneda K, Tanaka F, Kondo N, Hashimoto M, Takuwa T, Matsumoto $\mathrm{S}$, et al. Circulating tumor cells (CTCs) in malignant pleural mesothelioma (MPM). Ann Surg Oncol. (2014) 21 Suppl 4:S472-S480. doi: 10.1245/s10434-013-3399-2

116. Chikaishi Y, Yoneda K, Ohnaga T, Tanaka F. EpCAM-independent capture of circulating tumor cells with a 'universal CTC-chip'. Oncol Rep. (2017) 37:77-82. doi: 10.3892/or.2016.5235

117. Husain AN, Colby TV, Ordonez NG, Krausz T, Borczuk A, Cagle PT, et al. Guidelines for pathologic diagnosis of malignant mesothelioma: a consensus statement from the International Mesothelioma Interest Group. Arch Pathol Lab Med. (2009) 133:1317-31. doi: 10.1043/1543-2165-133.8.1317

118. Yoneda K, Kuwata T, Chikaishi Y, Mori M, Kanayama M, Takenaka $\mathrm{M}$, et al. Detection of circulating tumor cells with a novel microfluidic system in malignant pleural mesothelioma. Cancer Sci. (2019) 110:726-33. doi: $10.1111 /$ cas. 13895

119. Zucali PA, Giovannetti E, Destro A, Mencoboni M, Ceresoli GL, Gianoncelli L, et al. Thymidylate synthase and excision repair crosscomplementing group-1 as predictors of responsiveness in mesothelioma patients treated with pemetrexed/carboplatin. Clin Cancer Res. (2011) 17:2581-90. doi: 10.1158/1078-0432.ccr-10-2873

120. Christoph DC, Hoffmann AC, Gauler TC, Asuncion BR, Loewendick H, Peglow A, et al. Detection of circulating lung cancer cells with strong thymidylate synthase reactivity in the peripheral blood of a patient with pulmonary adenocarcinoma treated with pemetrexed. J Thorac Oncol. (2012) 7:766-7. doi: 10.1097/JTO.0b013e3182460fa9

121. Ramlau R, Thomas M, Novello S, Plummer R, Reck M, Kaneko T, et al. Phase I study of lapatinib and pemetrexed in the second-line treatment of advanced or metastatic non-small-cell lung cancer with assessment of circulating cell free thymidylate synthase RNA as a potential biomarker. Clin Lung Cancer. (2015) 16:348-57. doi: 10.1016/j.cllc.2015.01.004

Conflict of Interest Statement: The authors declare that the research was conducted in the absence of any commercial or financial relationships that could be construed as a potential conflict of interest.

Copyright (c) 2019 Cavallari, Urso, Sharova, Pasello and Ciminale. This is an openaccess article distributed under the terms of the Creative Commons Attribution License (CC BY). The use, distribution or reproduction in other forums is permitted, provided the original author(s) and the copyright owner(s) are credited and that the original publication in this journal is cited, in accordance with accepted academic practice. No use, distribution or reproduction is permitted which does not comply with these terms. 